\title{
Intercropping Barley (Hordeum vulgar L.) and Lentil (Lens culinaris L.): Yield and Intercropping Advantages
}

\author{
Mehdi Dahmardeh ${ }^{1}$ \\ ${ }^{1}$ Department of Agronomy, University of Zabol, Iran \\ Correspondence: Mehdi Dahmardeh, Department of Agronomy, University of Zabol, Iran. E-mail: \\ dahmard@yahoo.com,mdahmardeh@uoz.ac.ir
}

Received: August 10, 2012 Accepted: February 20, 2013 Online Published: March 15, 2013

doi:10.5539/jas.v5n4p209 URL: http://dx.doi.org/10.5539/ jas.v5n4p209

\begin{abstract}
Effect of intercropping of lentil with barley was studied at Department of Agronomy, University of Zabol, on a sandy loam soil during autumn 2011 growing season in order to determine biological and economical yield of barley (Hordeum vulgar L.) mixed with lentil (Lens culinaris L) cultivar mono cropped or intercropped in replacement series design. The treatments were compared in a randomized completely block design (RCBD) with five levels of row intercropping that was included: sole barley ( 6 row barley), 4 row barely +2 row lentil, 4 row lentil +2 row barley, 3 row barley +3 row lentil and sole lentil (6 row lentil) in three replication. Results indicated that intercropping system affected many characteristics such as plant height, biological and economical yield. Intercropped barley with lentil was far more effective than mono crop barley to produce yield and land equivalent ratio. The highest of LER for economical yield was obtained at 3 row barley +3 row lentil (2.61) and the least of LER was obtained by 2 row barley +4 row lentils. The results were shown that for get maximum production barely should be sown as an intercrop to lentil and the best treatment was It 3 row barley +3 row lentils in sistan region. Thus It can be concluded that mixture were advantageous compared to both sole crops of barley and lentil.
\end{abstract}

Keywords: Intercropping, LER, height plant, biological and economical yield

\section{Introduction}

Moreira (1989) was express that mixed cropping especially with legumes can betterment both forage quality and quantity because legumes are well source of protein. Intercropping of legumes and cereals is an old drill in tropical agriculture that dates back to old urbanity. The basis objective of intercropping has been to maximize benefit of resources such as area, light and nutrients (Li et al., 2003), as well as to recovery crop quality and quantity (Mpairwe et al., 2002). Ross et al. (2004) were showed that intercropping oat with pulse crops produced, greater Dry Matter yield than intercropping barley or triticale with pulse crops.

Others investigators have shown that intercropping of cereals and legumes produce higher grain yields than either sole crop (Mpairwe et al., 2002; Mucheru-Muna et al., 2010). In such intercropping, the yield development of the cereal component (Dahmardeh et al., 2010). Intercrops of legumes in cereals are a better election to increase the quality of cereal forages. However, intercropping gave higher crude protein yields than sole maize. Maize and cowpea intercropping gave higher total forage dry matter digestibility (DMD) than maize or cowpea sole crops and led to increased fodder quality, crude protein (CP) and dry matter digestibility (DMD) concentration than sole maize and higher water soluble carbohydrate (WSC) concentrations than sole cowpea (Dahmardeh et al., 2009). The efficiency of cereal-legume intercrops systems, to explain as land equivalent ratio (LER). Banik (1996) was showed that wheat and legumes (pea, lentil and gram) intercropping suggested that the intercropping advantage indicated that a 1:1 replacement series under all treatments was advantageous whereas a 2:1 replacement treatment (Banik, 1996). The seeing of the study was to determine the effect of intercropping lentil with barley, compared with sole crops. 


\section{Materials and Methods}

\subsection{Site}

The field experiment was carried out on the University of Zabol farm, Iran $\left(61^{\circ} 41^{\prime} \mathrm{E}, 30^{\circ} 54^{\prime} \mathrm{N}\right.$, and altitude 483 $\mathrm{m}$ above sea level); average 30 years rainfall was $49 \mathrm{~mm}$. The experiment was carried out during 2011 growing season on a sandy loam soil (Table 1).

All phosphorus (200 kg/ha) and potassium $(150 \mathrm{~kg} / \mathrm{ha})$ and half nitrogen $(75 \mathrm{~kg} / \mathrm{ha})$ were applied at sowing while balance of nitrogen was applied at stem elongation stage. All other cultural practices including (Irrigation, thinning and weeding) were kept normal and uniform for all the treatments.

Table 1. Soil characteristics of the experiment area during the 2011 growing season

\begin{tabular}{llllllllll}
\hline Year & Depth of soil $(\mathrm{cm})$ & $\mathrm{pH}$ & $\mathrm{Ec}(\mathrm{mmohs} / \mathrm{cm})$ & $\mathrm{N}(\%)$ & $\mathrm{P}(\mathrm{ppm})$ & $\mathrm{K}(\mathrm{ppm})$ & Sand & Silt & Clay \\
\hline 2011 & $0-20$ & 7.9 & 7.2 & 0.048 & 6.7 & 174 & 60 & 24 & 16 \\
\hline
\end{tabular}

\subsection{Experimental Design and Treatments}

The treatments were compared in a RCBD design with five levels of planting ratios: 3 row Barley +3 row Lentil (3B: 3L), 4 row Barley +2 row Lentil (4B: 2L), 2 row Barley +4 row Lentil (2B:4L), 6 row Barley $(6 \mathrm{~B})$ and 6 row Lentil $(6 \mathrm{~L})$ in three replication. The treatment comprising the individual plot size was $1.2 \mathrm{~m} \times 4 \mathrm{~m}$. For this experiment, the recommended density of barley and lentil are expressed, sole crop densities being 200 and 50 plants. $\mathrm{m}^{-2}$ barley and lentil, respectively. Initially 3 seeds were sown per hole. Two hand weeding was done 30 and 40 Day after sowing. Quantity parameters were determined includes: Biological yield, Economical yield, weight of 1000 seed, height of plant, harvest index for two plant and LER (land equivalent ratio).

\subsection{Statistical Analysis}

The data on growth, yield and quantity parameters were analyzed by Fisher's analysis of variance technique and Duncan test at 0.05 probability levels to compare means (Steel \& Torrie, 1984). Data analyses were conducted using of SAS (2001) as a RCBD experiment by 5 treatments with three replicates.

\section{Results and Discussion}

A perusal of data Table 2 indicated that quantitative parameters were significantly influenced by planting ratios of intercropping lentil and barley. A perusal of data (Table 2) indicated that biological yield, height plant and weight of 1000 seed were significantly influenced by different planting ratios of intercropping lentil and barley. Maximum economical yield for lentil $\left(21.6 \mathrm{~g} / \mathrm{m}^{2}\right)$ was recorded in plots where 2 rows B +4 rows L were sown. Minimum economical yield for lentil $\left(15.3 \mathrm{~g} / \mathrm{m}^{2}\right)$ was recorded in plots of sole lentil (Table 3), Maximum biological yield for lentil $\left(115.4 \mathrm{~g} / \mathrm{m}^{2}\right)$ was recorded in plots where 2 rows $\mathrm{B}+4$ rows $\mathrm{L}$ but Maximum biological yield for barley $\left(626.4 \mathrm{~g} / \mathrm{m}^{2}\right)$ was recorded in plots where 3 rows B +3 rows L were sown. Chen et al. (2004) found that, under low fertility conditions, a 50:50 mixture of barley and pea yielded as well as pure stands of barley that agree by this results.

Table 2. Analysis of variance for quantitative parameters of intercropping lentil and barley

\begin{tabular}{|c|c|c|c|c|c|c|c|c|c|c|c|}
\hline \multicolumn{12}{|c|}{ Means of Square } \\
\hline \multirow[b]{2}{*}{ S.OV } & \multirow[b]{2}{*}{$\mathrm{df}$} & \multicolumn{2}{|c|}{ Biological yield } & \multicolumn{2}{|c|}{ Economical yield } & \multicolumn{2}{|c|}{ Weight of 1000 seed } & \multicolumn{2}{|c|}{ Height plant } & \multicolumn{2}{|l|}{$\mathrm{HI}$} \\
\hline & & Barley & Lentil & Barley & Lentil & Barley & Lentil & Barley & Lentil & Barley & Lentil \\
\hline Replication & 2 & $5879.8^{\mathrm{ns}}$ & $32.9^{\mathrm{ns}}$ & $301.7^{\mathrm{ns}}$ & $2.22^{\mathrm{ns}}$ & $3.37^{\mathrm{ns}}$ & $0.11^{\mathrm{ns}}$ & $106.7^{\mathrm{ns}}$ & $26.3^{\mathrm{ns}}$ & $1.08^{\mathrm{ns}}$ & $1.5^{\mathrm{ns}}$ \\
\hline Treatment & 3 & $27349.4^{*}$ & $1773.2^{* *}$ & $1586.4^{\mathrm{ns}}$ & $25.6^{\mathrm{ns}}$ & $1.41^{\mathrm{ns}}$ & $13.8^{*}$ & $40.9^{* *}$ & $190.7^{*}$ & $5.5^{\text {ns }}$ & $0.001^{\mathrm{ns}}$ \\
\hline Error & 6 & 3207.5 & 117.9 & 374.9 & 10.8 & 1.54 & 1.7 & 1.3 & 29.3 & 0.002 & 0.002 \\
\hline C.V (\%) & - & 11.4 & 14.8 & 13.5 & 18.7 & 3.2 & 10.2 & 1.9 & 19.6 & 15.9 & 19.0 \\
\hline
\end{tabular}

${ }^{* * *}$ significant at $\mathrm{p}<0.05$ and $\mathrm{p}<0.01$, respectively.

HI: Harvest Index. 
Maximum weight of 1000 seed for lentil $(15.1 \mathrm{~g})$ was recorded in plots where 2 rows $\mathrm{B}+4$ rows $\mathrm{L}$ were sown but the maximum weight of 1000 seed for barley $(38.9 \mathrm{~g})$ was recorded in plots where 4 rows B +2 rows $\mathrm{L}$ were sown. Minimum weight of 1000 seed for lentil (9.9 g) was recorded in plots of sole lentil (Table 3), but Minimum weight of 1000 seed for barley $(37.4 \mathrm{~g})$ was recorded in plots where 3 rows B +3 rows L were sown. The results were shown that the highest of height plant for lentil $(36.3 \mathrm{~cm})$ was recorded in plots where 2 rows $\mathrm{B}$ +4 rows $\mathrm{L}$ were sown but the maximum height plant for barley $(62 \mathrm{~cm})$ was recorded in plots where 4 rows $\mathrm{B}+$ 2 rows L were sown. Minimum Height plant for lentil $(17 \mathrm{~cm}$ ) was recorded in plots of sole lentil (Table 3), but Minimum Height plant for barley $(53.3 \mathrm{~cm})$ was recorded in plots where 2 rows $\mathrm{B}+4$ rows $\mathrm{L}$ were sown. The results were shown that the maximum of $\mathrm{HI}$ for lentil $(29 \%)$ was recorded in plots where 4 rows B +2 rows $\mathrm{L}$ were sown but the maximum $\mathrm{HI}$ for barley $(30 \%)$ was recorded in plots where 2 rows B +4 rows L were sown. Minimum HI for lentil (18\%) was recorded in plots of 2 rows B +4 rows L (Table 3), but Minimum HI for barley $(27 \%)$ was recorded in plots where 3 rows $\mathrm{B}+3$ rows $\mathrm{L}$ were sown.

Table 3. Means of Economical and Biological Yield, Weight of 1000 seed, Height plant (cm) and HI of lentil and barley as influenced by different Planting Ratios

\begin{tabular}{|c|c|c|c|c|c|c|c|c|c|c|}
\hline \multirow{2}{*}{$\begin{array}{l}\text { Planting Ratio } \\
\text { Lentil : Barley }\end{array}$} & \multicolumn{2}{|c|}{ Economical Yield $\left(\mathrm{g} / \mathrm{m}^{2}\right)$} & \multicolumn{2}{|c|}{ Biological Yield $\left(\mathrm{g} / \mathrm{m}^{2}\right)$} & \multicolumn{2}{|c|}{ Weight of 1000 seed } & \multicolumn{2}{|c|}{ Height plant(cm) } & \multicolumn{2}{|l|}{ HI } \\
\hline & Lentil & Barley & Lentil & Barley & Lentil & Barley & Lentil & Barley & Lentil & Barley \\
\hline 4 row $L+2$ row $B$ & $21.6 \mathrm{a}$ & $136.1 \mathrm{ab}$ & $115.4 \mathrm{a}$ & $438.0 \mathrm{~b}$ & $15.1 \mathrm{a}$ & $38.7 \mathrm{a}$ & $36.3 \mathrm{a}$ & $53.3 \mathrm{~d}$ & $0.18 \mathrm{a}$ & $0.30 \mathrm{a}$ \\
\hline 2 row $L+4$ row $B$ & $21.3 \mathrm{a}$ & $144.2 \mathrm{ab}$ & $71.1 \mathrm{~b}$ & $506.0 \mathrm{~b}$ & $13.1 \mathrm{a}$ & $38.9 \mathrm{a}$ & $29 \mathrm{a}$ & $62 \mathrm{a}$ & $0.29 \mathrm{a}$ & $0.28 \mathrm{a}$ \\
\hline 3 row $L+3$ row $B$ & $17.7 \mathrm{a}$ & $173.8 \mathrm{a}$ & $68.9 b$ & $626.4 a$ & $13.1 \mathrm{a}$ & $37.4 \mathrm{a}$ & $28 \mathrm{a}$ & $55.6 \mathrm{c}$ & $0.25 \mathrm{a}$ & $0.27 \mathrm{a}$ \\
\hline 6 row barley & - & $118.7 \mathrm{~b}$ & - & $413.0 \mathrm{~b}$ & - & $38.1 \mathrm{a}$ & - & $58 \mathrm{~b}$ & - & $0.28 \mathrm{a}$ \\
\hline 6 row lentil & $15.3 \mathrm{a}$ & - & $62.2 b$ & - & $9.9 \mathrm{~b}$ & - & $17 b$ & - & $0.24 \mathrm{a}$ & - \\
\hline LSD & 6.5 & 38.6 & 21.6 & 113.1 & 2.6 & 2.4 & 10.8 & 2.2 & 0.09 & 0.10 \\
\hline
\end{tabular}

Any two means not sharing a common letter differ significantly from each other at $5 \%$ probability.

\subsection{Land Equivalent Ratio (LER)}

Higher LER in intercropping treatments indicated yield advantage over mono cropping due to better land utilization. Partial LER of Lentil decreased as the proportion of barley increased in mix- proportions (Table 3). Higher LER in intercropping treatment indicated yield advantage over sole cropping due to better land utilization. The mean LER values were always greater than 1.0 (Table 3). Advantage from non legume-legume intercropping systems has been reported previously in crops such as wheat and legume (Banik, 1996), pea and barley (Chen et al., 2004), field bean and wheat (Bulson et al., 1997) and maize and faba bean (Li et al., 1999).

Table 3. Means of LER of Lentil and Barley as influenced by different Planting Ratios

\begin{tabular}{llll}
\hline Planting ratio & LER & & \\
\hline Lentil: Barley & Lentil & Barley & Total LER \\
\hline 4 row L+2 row B & 1.41 a & 1.14 a & $2.55 \mathrm{a}$ \\
2 row L+4 row B & 1.39 a & 1.21 a & $2.60 \mathrm{a}$ \\
3 row L+3 row B & 1.15 a & 1.46 a & $2.61 \mathrm{a}$
\end{tabular}

Any two means not sharing a common letter differ significantly from each other at $5 \%$ probability.

The highest (Land Equivalent Ratio) LER was obtained by sowing the crop in a ratio of 3 row L +3 row B (2.61) and the lowest LER was obtained by sowing the crops in 4 row $\mathrm{L}+2$ row B (2.55). LER values were greater than one in all intercropping systems which indicated yield advantage of intercropping. Dhima et al. (2007) were shown that when LER is greater than 1, the intercropping well the growth and yield of the species. In contrast, when LER is lower than 1, the intercropping negatively influence the growth and yield of plants grown in mixtures. The LER values were greater than one, indicating more efficient benefits of plant growth factors by intercrops compared to sole crops (Francis \& Sanders, 1978). Facilitative root interactions are most likely to be 
of importance in nutrient-poor soils and low input agro ecosystems due to crisis inter specific competition or facilitation for plant growth factors (Hauggaard-Nielsen et al., 2001). Because of the spatial and temporal different in the growth factors and different crop species; intercropped plants could improvement utilize nutrients from soils compared with sole cropped plants (Sharma \& Gupta, 2002; Zhang \& Li, 2003).

\section{Conclusion}

The reason could be due to the facilitative effect of lentil, which can uptake part of its nitrogen requirements through symbiotic biological nitrogen fix which, in turn, reduces the over overcharge pressure on soil nitrogen stock. A facilitative production principle is proposed based on several years of studies on intercropping. This means that inter specific interaction increases the growth, nutrient uptake and yield of dominant species, but decreases the growth and nutrient uptake of the subordinate species during the co-existence stage of the two crop species (Zhang \& Li, 2003). Nitrogen fixing ability of faba bean roots and transfer of $\mathrm{N}$ fixed by faba bean to maize, extensive root system of maize for absorption of water and nutrients and less competition of faba bean with maize resulted in no significant change in grain yield of maize at different densities of intercropping (Chen et al., 2004). Possible that lentil via $\mathrm{N}_{2}$ fixation could secrete $\mathrm{H}^{+}$in soil; this acidification of the rhizo sphere could improvement dissolution of phosphorus in high pH soils (Hinsinger, 2001). Therefore, lentil prepare nitrogen and phosphorus for itself and barley in intercropping. This can increase total grain yield of two crops in intercropping system. From the above it can be concluded that there are opportunities for improving the productivity of Lentil/Barley in the southeast of Iran at the arid ecological zone using of intercropping is the best cropping systems, because at this system high yield was higher than compared to other sole crops. It is obvious from the results that Lentil and Barley intercropping are more effective compared to sole cropping.

\section{References}

Banik, P. (1996). Evaluation of Wheat (Triticum aestivum) and Legume Intercropping Under 1:1 and 2:1 $\begin{array}{lllllll}\text { Row-replacement Series System. J. Agron. } & \text { Crop } & \text { Sci., } & 1, & 364-374 .\end{array}$ http://dx.doi.org/10.1111/j.1439-037X.1996.tb00473.x

Bulson, H. A. J., Snaydon, R. W., \& Stopes, C. E. (1997). Effects of plant density on intercropped wheat and filed beans in an organic farming system. J. Agr. Sci., 128, 59-71. http://dx.doi.org/10.1017/S0021859696003759

Chen, C., Westcott, M., Neill, K., Wichman, D., \& Knox, M. (2004). Row Configuration and Nitrogen Application for Barley-pea Intercropping in Montana. Agron. J., 96, 1730-1738. http://dx.doi.org/10.2134/agronj2004.1730

Dahmardeh, M., Ghanbari, A., Syahsar, B. A., \& Ramrodi, M. (2010). The role of intercropping maize (Zea mays L.) and Cowpea (Vigna unguiculata L.) on yield and soil chemical properties. African Journal of Agricultural Research, 5(8), 631-636. http://dx.doi.org/10.5897/AJAR09.607

Dhima, K. V., Lithourgidis, A. S., Vasilakoglou, I. B., \& Dordas, C. A. (2007). Competition indices of common vetch and cereal intercrops in two seeding ratio. Field Crops Res., 100, 249-256. http://dx.doi.org/10.1016/j.fcr.2006.07.008

Francis, C. A., \& Sanders, J. H. (1978). Economic analysis of bean and maize systems: monoculture versus associated cropping. Field Crops Research, 1, 319-335. http://dx.doi.org/10.1016/0378-4290(78)90034-5

Hauggaard-Nielsen, H., Ambus, P., \& Jensen, E. S. (2001). Interspecific competition, N use and interference with weeds in pea-barley intercropping. Field. Crops. Res., 70, 101-109. http://dx.doi.org/10.1016/S0378-4290(01)00126-5

Hinsinger, P. (2001). Bioavailability of soil inorganic $\mathrm{P}$ in the rhizo sphere as affected by root-induced chemical changes: A review. Plant Soil, 237, 173-137. http://dx.doi.org/10.1023/A:1013351617532

Li, L., Yang, S., Li, X., Zhang, F., \& Christie, P. (1999). Inter specific complementary and competitive interactions between intercropped maize and faba bean. Plant Soil, 212, 105-114. http://dx.doi.org/10.1023/A:1004656205144

Li, L., Zhang, F. S., Li, X. L., Christie, P., Sun, J. H., Yang, S. C., \& Tang, C. (2003). Inter specific facilitation of nutrient uptake by intercropped maize and faba bean. Nutrient Cycling in Agro Eco, 68, 61-71. http://dx.doi.org/10.1023/A:1021885032241

Moreira, N. (1989). The effect of seed rate and nitrogen fertilizer on the yield and nutritive value of oat-vetch mixtures. J. Agric. Sci. Camb, 112(1), 57-66. http://dx.doi.org/10.1017/S0021859600084100 
Mpairwe, D. R., Sabiiti, E. N., Ummuna, N. N., Tegegne, A., \& Osuji, P. (2002). Effect of intercropping cereal crops with forage legumes and source of nutrients on cereal grain yield and fodder dry matter yields. Afr. Crop. Sci. J., 10, 81-97. http://dx.doi.org/10.4314/acsj.v10i1.27559

Mucheru-Muna, M., Pypers, P., Mugendi, D., Kung'u, J., Mugwe, J., Merckx, R., \& Vanlauwe, B. (2010). A staggered maizelegume intercrop arrangement robustly increases crop yields and economic returns in the highlands of Central Kenya. Field Crops Res., 115,132-139. http://dx.doi.org/10.1016/j.fcr.2009.10.013

Ross, S. M., King, J. R., O’donovan, J. T., \& Spaner, D. (2004). Intercropping Berseem Clover with Barley and Oat Cultivars for Forage. Agron. J., 96, 1719-1729. http://dx.doi.org/10.2134/agronj2004.1719

SAS, Institute. (2001). SAS Procedure Guide. Version 8.2, SAS Inst., Cary, NC 2001. Retrieved from $\mathrm{http}: / /$ www.google.com/search?hl=en\&lr=lang_en\&q=\%22Guide $\% 22+\% 22$ Cary $\% 22$

Sharma, O. P., \& Gupta, A. K. (2002). Nitrogen-phosphorus nutrition of pearl millet as influenced by intercrop legumes and fertilizer levels. J. Plant Nutr., 25, 833-842. http://dx.doi.org/10.1081/PLN-120002963

Steel, R. G. D., \& Torrie, J. H. (1984). Principles and Procedures of Statistics (pp. 172-178) (2nd ed.). Singapore: McGraw Hill Book Co. Inc. Retrieved from http://www.garfield.library.upenn.edu/classics1977/A1977DU23500002.pdf

Zhang, F., \& Li, L. (2003). Using Competitive and Facilitative Interactions in Intercropping Systems Enhances Crop Productivity and Nutrient-use Efficiency. Plant and Soil., 248, 305-312. http://dx.doi.org/10.1023/A:1022352229863 